\title{
Strategi Pengamanan Wilayah Oleh Skuadron Udara 51 UAV
}

\section{(Territorial Security Strategy by the 51 UAV Air Squadron)}

\author{
M. Nurdi Iriansyah ${ }^{1 *}$, Heri Casnoto $^{2}$, Yusa Djuyandi ${ }^{3}$ \\ ${ }^{1}$ Sesko AU, Bandung, Indonesia \\ E-mail: Nurdi2007@ gmail.com \\ ${ }^{2}$ Bappelitbang Kota Bandung, Indonesia \\ E-mail: casnoto1977@yahoo.co.id \\ ${ }^{3}$ Universitas Padjadjaran Bandung, Indonesia \\ E-mail: yusa.djuyandi@unpad.ac.id
}

\begin{abstract}
The security of Indonesia's territorial territory requires a breakthrough in terms of regional security strategies. This is due to the limitation of resources owned by the government compared to the area for which it is responsible. Advances in science and technology in the use of Unmanned Aerial Vehicles (UAVs) have provided breakthroughs as a solution in regional security strategies more effectively and efficiently without compromising the quality of regional security. The Air Force through the 51 UAVs Air Squadron, as an air squadron that relies on the use of UAVs, has proven that the use of UAVs is capable of making a real contribution to the security strategy of the region. This is evidenced by the involvement of the 51 UAV Air Squadron in several operations that provide optimal results in terms of surveillance of the intended object. With reference to the advantages possessed by the 51 UAV Air Squadron, it can be concluded that the role of UAVs in the strategy of securing the region is significant. As a follow-up, efforts are needed to increase the breadth of UAV range and use surveillance results more widely with cross-institutional that can be expanded so that its use can be maximized.
\end{abstract}

Keywords-Regional Security Strategy, Surveillance and UAVs

Abstrak-Pengamanan wilayah teritorial Indonesia membutuhkan terobosan dalam hal strategi pengamanan wilayah. Hal tersebut disebabkan adanya keterbatasan sumber daya yang dimiliki pemerintah dibandingkan dengan luas wilayah yang menjadi tanggung jawabnya. Kemajuan iptek dalam penggunaan Unmanned Aerial Vehicles (UAV) telah memberikan terobosan sebagai solusi dalam strategi pengamanan wilayah secara lebih efektif dan efisien tanpa mengurangi kualitas pengamanan wilayah. TNI AU melalui Skuadron Udara 51 UAV, sebagai Skuadron Udara yang bertumpu pada penggunaan UAV, telah membuktikan bahwa penggunaan UAV mampu memberi kontribusi nyata pada strategi pengamanan wilayah. Ini dibuktikan dengan keterlibatan Skuadron Udara 51 UAV pada beberapa operasi yang memberikan hasil optimal dalam hal surveillance terhadap sasaraan/objek yang dituju. Dengan mengacu pada keunggulan yang dimiliki oleh Skuadron Udara 51 UAV, maka dapat disimpulkan bahwa peran UAV dalam strategi pengamanan wilayah signifikan adanya. Sebagai tindak lanjut, diperlukan upaya peningkatan keluasan jangkauan UAV serta pemanfaatan hasil surveillance secara lebih luas dengan lintas institusi yang dapat diperluas sehingga penggunaannya dapat lebih dimaksimalkan.

Kata Kunci-Strategi Pengamanan Wilayah, Surveillance dan UAV 


\section{Pendahuluan}

Sebagai negara dengan wilayah terluas nomor lima belas di dunia[1], Indonesia dihadapkan

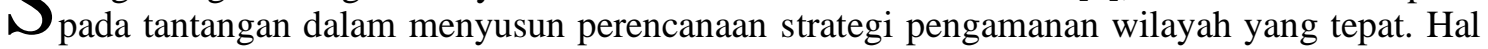
ini diperlukan, karena kekeliruan dalam pemilihan strategi pengamanan wilayah dapat berdampak pada kedaulatan negara. Kini, strategi pengamanan wilayah telah berkembang, dan mulai meninggalkan cara-cara konvensional, menggunakan pola-pola baru yang lebih andal dalam menjaga kedaulatan negara. Apalagi rasio jumlah TNI terhadap penduduk yang mencapai 1 : 613 atau sebesar 0,00163\% jauh lebih rendah dari Malaysia yang hanya 1 : 296 atau $0,00465 \%$. Dengan situasi seperti ini tentu diperlukan terobosan baru yang nyata, dan hal Ini menjadi penting mengingat hasil studi menunjukkan. Dalam hal keamanan wilayah, Indonesia masuk pada kategori low resource availability/low-threat strategic environment [2].

Salah satu terobosan yang dapat dilakukan, adalah berkaitan dengan pemanfaatan hasil perkembangan teknologi seperti UAV yang telah membawa cakrawala baru dalam hal strategi pengamanan wilayah. Teknologi Unmanned Aerial Vehicles (UAV) atau pesawat tak berawak atau oleh sebagian masyarakat umum dikenal dengan nama drone, mulai mengambil alih peran model konvensional yang mengandalkan pesawat tempur maupun pengamatan visual langsung. Penyerangan yang ditargetkan melalui serangan pesawat tak berawak ini telah mengubah ruang pertempuran, membuat pendudukan fisik tidak diperlukan lagi. Selain itu, UAV dapat melakukan bentuk perintah yang kompleks tanpa batas di ruang yang sulit diatur yang dipenuhi dengan ketidakpastian, kekerasan, dan bahaya[3]. Kedepan, tren ini nampaknya akan terus berlanjut dan semakin kuat.

Lebih jauh, UAV telah menjadi game changer dalam sebuah peperangan. Terbukti, pada perang enam pekan di musim gugur tahun 2020, angkatan bersenjata Azerbaijan mampu menghancurkan baterai artileri Armenia dengan mengandalkan UAV. Selama perang berlangsung, Azerbaijan sangat mengandalkan penggunaan pesawat tak berawak/UAV untuk mengidentifikasi, menargetkan, dan menyerang posisi-posisi pertahanan dan unit-unit lapis baja Armenia[4]. Hasilnya Armenia pun harus kehilangan wilayah Nagorno-Karabakh. Hal tersebut nampaknya sejalan dengan pandangan Gregory[3] yang menyatakan bahwa dalam perang modern saat ini telah dimanfaatkan teknologi untuk menghasilkan hasil maksimal, namun minim kerugian serta dapat menjangkau area perang yang tidak terbatas. Selanjutnya juga dikatakan bahwa setelah peristiwa 11 September, perang kemudian digambarkan menjadi panjang atau permanen dan bergantung pada inovasi teknologi, jaringan dan informasi. Ini berbeda dengan strategi perang sebelumya yang menitikberatkan pada perebutaan wilayah dalam upaya memenangkan perang[14].

Pada Buku Putih Kementerian Pertahanan Tahun 2015 disebutkan bahwa rekayasa teknologi berkembang di dunia penerbangan, pembuatan senjata nuklir maupun wahana peluncur roket, peluru kendali maupun wahana terbang tanpa awak serta teknologi satelit juga dimanfaatkan untuk kepentingan pertahanan negara[5]. Menyikapi hal tersebut, TNI-AU telah membentuk dan memiliki Skuadron Udara 51 UAV sebagai Skuadron Udara pertama di Indonesia yang menggunakan UAV sebagai tulang punggung kekuatannya. Pengunaan UAV ini merupakan jawaban atas tantangan dan peluang penggunaan teknologi UAV dalam perencanaan pengamanan wilayah terbuka yang niscaya menjadi sangat penting. Apalagi jika mengingat luasnya wilayah Indonesia dan dihadapkan pada keadaan alam yang terbilang tidak mudah. Tulisan ini mendeskripsikan tentang bagaimana strategi pengamanan wilayah yang dilakukan oleh Skuadron Udara 51 UAV.

\section{LANDASAN TEORI}

Strategi pengamanan wilayah menjadi bahasan yang sering didiskusikan oleh banyak ahli di sektor keamanan. Hal ini berkaitan dengan tingkat ketersediaan sumber daya dan lingkungan 
strategis ancaman untuk mengadopsi strategi perilaku guna mengatasi masalah spesifik yang secara langsung menantang kelangsungan hidup dan kedaulatan suatu negara.

\section{A. Perencanaan Strategi Pengamanan Wilayah}

Dalam analisis tentang bagaimana suatu wilayah dapat terbangun rasa aman dari adanya kemungkinan serangan negara lain, atau karena adanya situasi konflik antar dua negara dalam suatu wilayah, maka negara di kawasan dapat menjalankan sebuah strategi pengamanan wilayah yang dinamakan dengan Strategi Hedging, yaitu seperangkat strategi yang ditujukan untuk menghindari (atau merencanakan kemungkinan dalam) situasi di mana negara tidak dapat memutuskan alternatif yang lebih langsung seperti penyeimbangan, ikut-ikutan (bandwagoning), atau netralitas[6]. Dalam bahasan tentang bagaimana suatu keamanan dapat terbangun di suatu wilayah, maka dibutuhkan adanya suatu strategi pengamanan yang baik dengan diantaranya melakukan suatu proses mitigasi ancaman-ancaman yang mungkin membahayakan keamanan wilayah atau negara. Proses mitigasi atas ancaman keamanan ini bisa dilakukan dengan menggunakan berbagai fasilitas, peralatan militer, serta latihan[7].

Pandangan lainnya tentang strategi keamanan nasional, menjelaskan bahwa setidaknya harus ada minimal tiga kemampuan dasar dalam pengembangan strategi keamanan nasional, yaitu: harus adanya keamanan berbasis pengetahuan, keamanan berbasis keterampilan, dan keamanan berbasis regulasi. Keamanan berbasis pengetahuan didasarkan pada informasi intelijen yang akurat, cepat, lengkap dan benar. Pengamanan berbasis keterampilan lebih bertumpu pada kekuatan fisik yang berwujud, seperti postur kekuatan. Sedangkan keamanan berbasis regulasi didasarkan pada penerapan aturan yang ketat dan benar[8].

Munculnya keragaman ancaman global saat ini seperti terorisme, dikombinasikan dengan munculnya kemajuan teknologi informasi dan komputasi baru, memberi kontribusi terhadap efisiensi penggunaan personel militer, terutama dalam hal taktis dan kecepatan dalam pengambilan keputusan. Paling penting, penerapan teknologi informasi untuk persenjataan baru menghasilkan perkembangan selanjutnya dari filosofi perang modern yang ramping dan mengilhami proses perubahan teknologi, administratif, dan politik yang menjadi ciri militer[9].

Kajian mengenai strategi keamanan wilayah memiliki suatu cakupan yang luas, sehingga tidak ada suatu pandangan yang tetap untuk menentukan bagaimana strategi pengamanan wilayah atau keamanan itu bisa dilakukan. Akan tetapi dalam kajian yang berkenaan dengan strategi pengamanan wilayah oleh Skadron Udara $51 \mathrm{UAV}$, peneliti merujuk pada suatu diskusi literatur yang berfokus pada bagaimana mencegah serangan keamanan dengan menggunakan sejumlah strategi yang layak digunakan seperti pencegahan, deteksi dini dan respon[10].

\section{B. Penggunaan Teknologi UAV}

Pesawat yang dikemudikan dari jarak jauh telah digunakan sejak Perang Dunia Pertama, pesawat tak berawak dikerahkan pada tahap akhir Perang Dunia Kedua. Sedangkan penggunaan kendaraan udara tak berawak (UAV) dalam pertempuran besar pertama adalah selama Perang Vietnam[11]. Ini menunjukkan ada sejarah yang cukup besar di balik operasi jarak jauh hari ini. Perkembangan teknologi aeronautika berkembang dengan sangat cepat, Saat ini, UAV telah dapat melakukan berbagai tugas yang mengesankan, mulai dari operasi militer hingga membantu kehidupan manusia, dan berdasarkan ukurannya, UAV bisa berukuran sebesar pesawat terbang atau bahkan lebih kecil, sekecil telapak tangan [12].

Penggunaan UAV semakin marak dan cukup berpotensi menjadi ancaman bagi pertahanan negara, karena UAV dapat digunakan untuk melakukan serangan terhadap berbagai objek sasaran di permukaan. Untuk mencegah dampak yang tidak diinginkan baik dari aspek 
pertahanan negara maupun keselamatan penerbangan, maka perlu diputuskan penggunaan UAV[13]. UAV tidak dibatasi oleh kinerja manusia atau karakteristik fisiologis. Ketekunan dan kemampuan manuvernya yang ekstrem menjadi manfaat intrinsik tersendiri. Dengan kata lain, UAV dapat menangani atau melakukan apa saja yang tidak bisa dilakukan manusia [14] karena keterbatasan - kekuatan dan tekanan G-Force serta kebosanan[15].

Manfaat intrinsik UAV lainnya: UAV dapat menghilangkan target manusia/dari musuh dengan cepat dan senyap; tidak mengenal rasa lelah atau haus serta lapar; relatif murah; dan dengan datangnya UAV bertenaga nuklir, mereka menawarkan kemungkinan operasi di atas target yang hampir tak ada habisnya[15]. Atas dasar hal tersebut, dalam kacamata militer, kendaraan udara tempur tak berawak/UAV ini telah menjadi senjata yang ikonik dalam peperangan modern[16] dan bahkan menjadi keajaiban bagi senjata perang hari ini[17]. UAV bahkan telah menjadi salah satu tulang punggung AS dalam perang melawan teroris dan pemberontak[18]. UAV juga dinilai telah digunakan untuk menyerang barisan konvoi yang membawa Moammar Qaddafi; membunuh Abu Yahya al Libi dan Anwar al Awlaki dari al Qaeda; jajaran Taliban dan militan lainnya di teater Afghanistan dan Pakistan; dan mencapai target dari Asia hingga Afrika - semuanya berlangsung tanpa membahayakan pilot[12]. Namun demikian terbuka peluang lain terhadap penggunaan UAV baik selain untuk tujuan perang maupun juga untuk tujuan damai dalam mendukung operasi militer.

Meski memiliki ketenaran saat digunakan pada zona perang di Afghanistan, Irak, dan Pakistan Utara, UAV juga digunakan untuk mengelola keadaan darurat yang disebabkan oleh bencana alam, memata-matai kartel narkoba asing, menemukan aktivitas kriminal di daerah perkotaan dan pedesaan, serta melakukan operasi kontrol perbatasan[19]. UAV dapat terbang dan dikendalikan dari jarak jauh atau diprogram untuk mencapai target tertentu dan dilengkapi dengan kamera, sensor, perangkat komunikasi, serta perangkat lainnya. Pemanfaatan UAV saat ini sangat beragam seperti untuk keperluan survei, pemotretan, pemantau cuaca dan berbagai kepentingan lainnya, baik untuk kepentingan militer maupun non-militer bahkan untuk kepentingan komersial[11]

\section{Peran SkUadron Udara 51 UAV}

\section{A. Strategi Pengamanan Wilayah dengan UAV}

UAV atau sering juga oleh Sebagian masyarakat umum disebut drone saat ini digunakan untuk memantau berbagai aktivitas melalui udara dan pemanfaatannya kini tidak hanya digunakan untuk kepentingan militer dan negara, tetapi juga oleh masyarakat serta lembaga sipil yang dipergunakan untuk berbagai keperluan seperti pemetaan wilayah, liputan pemberitaan, maupun hobi. Dari segi kepentingan keamanan wilayah, UAV dapat digunakan untuk memantau aktivitas yang berpotensi mengancam atau menggangu keamanan wilayah, seperti memantau kawasan perbatasan negara, pergerakan kelompok teroris dan separatis, penyelundupan atau transaksi barang illegal (narkotika dan obat-obatan terlarang, senjata, kayu illegal, dan lain sebagainya). Bagi kepentingan pertahanan negara, UAV dapat digunakan untuk pemetaan wilayah pertahanan yang dilakukan oleh pemerintah melalui Kementerian Pertahanan, bersama-sama dengan TNI, atau dengan kemampuan yang lebih tinggi melakukan aksi pertahanan dengan diperlengkapi senjata.

Penggunaan UAV dalam dunia militer diklaim mampu mereduksi pengeluaran belanja operasional dan memberikan efisiensi, sehingga alokasi dana dapat diperuntukan untuk kebutuhan pertahanan lainnya. Dilihat dari sisi pengoperasiannya, penggunaan UAV mampu meniadakan jatuhnya korban jiwa/personel ketika pesawat UAV digunakan untuk keperluan operasi militer. Teknologi yang mutakhir membuat UAV mampu memantau secara langsung objek yang sedang diamati, baik yang ada di udara, darat dan laut. UAV juga mampu 
mengamati objek di lokasi-lokasi yang dianggap cukup ekstrem dan sulit dijangkau oleh operasi pengawasan yang bersifat konvensional.

Skuadron Udara 51 UAV adalah Skuadron Udara pertama di Indonesia yang mengoperasikan pesawat nirawak atau kita kenal dengan UAV, dengan tugas pokok melaksanakan pengamanan wilayah dan patroli maritim terutama di wilayah Kalimantan Barat. Skuadron ini mengandalkan pesawat UAV yang memiliki kemampuan terbang jelajah hingga 18.000 feet dan memiliki endurance selama 10 jam, serta jarak jelajah mencapai radius $250 \mathrm{~km}$. Dilengkapi kamera (payload) DSP dan Quad, wahana ini mampu merekam dan menyajikan data secara real time baik siang maupun malam sehingga sangat membantu pengambilan keputusan dalam suatu operasi. UAV mampu melakukan kegiatan seperti Battlefield Surveillance, Target Acquisition and Designation, Artilery Fire Adjustment, Air Strike Control, Border Patrol, Coast Guard Survellance, Inteligent Operation. Dari kegiatan seperti tersebut, hanya misi Artilery Fire Adjustment dan Air Strike Control yang bukan menjadi bagian dari penggunaan untuk pengamanan wilayah disini.

Mengacu pada model strategi keamanan di suatu wilayah, Skuadron Udara 51 UAV menjadi bagian dari proses mitigasi ancaman yang dapat membahayakan keamanan wilayah dengan memanfaatkan teknologi[7]. Melalui hal ini Skuadron Udara 51 UAV dapat memberikan informasi melalui kegiatan surveillance, dengan hasil yang cepat, tepat dan berguna untuk membentuk strategi pengamanan wilayah guna mencegah ancaman melalui upaya pencegahan, deteksi dan respon.

Hal ini menjadi penting karena UAV telah mengubah konsep "desain teritorial" yang menekankan pada tiga dimensi penting wilayah: ciri fisiknya, proses demarkasinya, dan konstitusi ruang demarkasi atau teritorial. Dimensi kedua dan ketiga menyoroti sifat wilayah yang produktif dan berubah - apa yang mungkin kita sejajarkan dengan Elden untuk mulasi wilayah sebagai teknologi politik. Pemeriksaan perang UAV kontemporer melalui konteks pembenaran hukum untuk serangan ekstra-teritorial menggambarkan perlunya pemahaman wilayah yang dinamis serta pentingnya wilayah untuk perumusan kebijakan luar negeri dan perluasan kekerasan negara dan otoritas[8].

Pentingnya UAV untuk pelaksanaan perang telah dibuktikan melalui praktik: penggunaan UAV bersenjata dalam lima belas tahun terakhir yang berkembang secara pesat. Meskipun awalnya dikembangkan untuk tujuan/kepentingan intelijen namun pada pertengahan tahun 1990-an, UAV kemudian telah dipersenjatai[20]. Dan pada tanggal 4 Februari 2002, CIA menjadi organisasi pertama yang menggunakan pesawat tak berawak/UAV Predator untuk melakukan serangan dan pembunuhan terhadap obyek yang telah ditargetkan. Setelah itu ribuan serangan pesawat tak berawak pun tercatat, dan teknologi ini kemudian terus berkembang biak: Sebelas negara bagian, termasuk AS, Inggris, Israel, Pakistan, China, dan Nigeria, serta empat aktor non-negara lain kemudian diketahui telah memiliki UAV bersenjata, dengan potensi proliferasi lebih lanjut yang diakui.

\section{B. Pelibatan dalam Operasi}

Dengan kemampuannya sebagai mata di langit, Skuadron Udara 51 UAV memiliki peran penting dalam menjamin kemanan dan kedaulatan NKRI termasuk di wilayah perairan ALKI I. Melalui ketinggian 16.000 kaki UAV mampu mendeteksi dini berbagai aktivitas jenis kapal baik kapal penangkap ikan maupun kargo yang melintas di wilayah ALKI I. Pengamanan ALKI ini telah diatur sebagaimana yang tertulis dalam Peraturan Pemerintah Republik Indonesia Nomor 37 Tahun 2002 Tentang Hak dan Kewajiban Kapal dan Pesawat Udara Asing dalam Melaksanakan Hak Lintas Alur Laut Kepulauan Melalui Alur Laut Kepulauan yang Ditetapkan. 


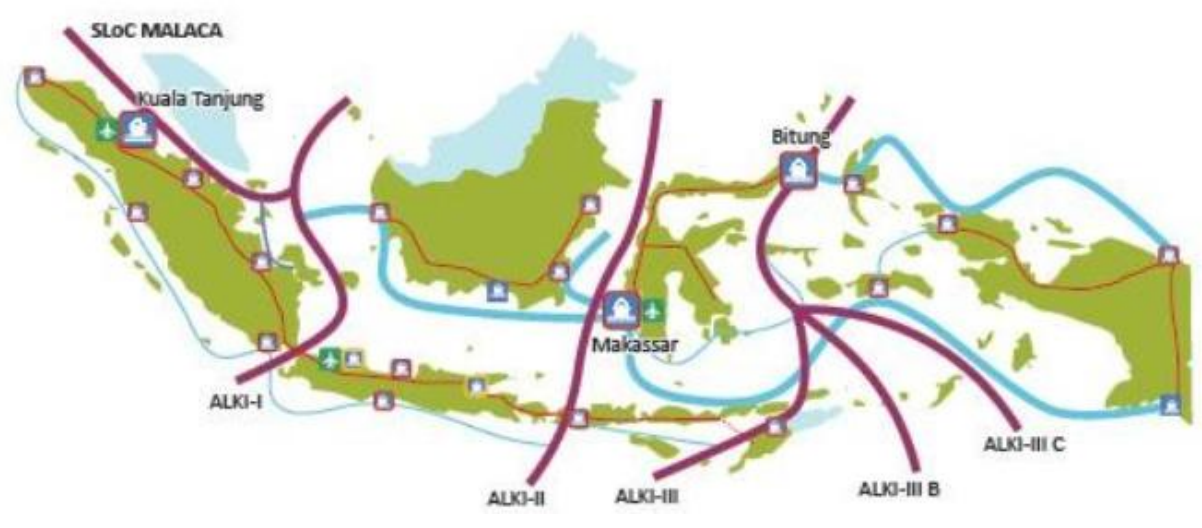

Sumber : https://docplayer.info/54695625-Alur-laut-kepulauan-indonesia-alki-i-ii-iii.html ${ }^{17}$

Gambar 1. ALKI Indonesia sesuai PP No. 37 Tahun 2002

Skuadron Udara 51 juga terlibat dalam upaya penanganan tindak pidana terorisme seperti pada kelompok Santoso, yang dilibatkan pada Operasi Tinombala bersama TNI dan Polri di Poso Sulawesi Tengah. Dengan melakukan pengamatan di berbagai area pegunungan Poso baik siang maupun malam hari. Hingga kemudian memperoleh hasil identifikasi berupa pergerakan kelompok teroris Santoso. Citra yang dihasilkan, selain menemukan beberapa orang yang membentuk formasi regu, juga menemukan tempat persembunyian kawanan Santoso. Informasi ini kemudian ditindaklanjuti ke pasukan kawan dilapangan, yang kemudian berhasil melumpuhkan kelompok teroris ini.

Skuadron Udara 51 juga terlibat dalam Satuan Tugas Khusus Pembebasan Sandera yang tergabung dalam sekumpulan pasukan khusus baik dari matra darat, laut dan udara sebagai unsur pengintai melalui udara. Hal ini terjadi pada saat terjadi krisis berkaitan dengan penyanderaan ABK oleh kelompok Abu Sayyaf terhadap sepuluh WNI yang bekerja sebagai ABK kapal tugboat TB Brahma 12. Selanjutnya keterlibatan lain juga terus berlanjut dengan ikut sertanya Skuadron Udara 51 UAV pada Operasi Pengamanan Daerah Rawan (Opspamrahwan) 2017 di wilayah (Timika) Papua yang dilaksanakan oleh Skuadron Udara 51 UAV menggunakan homebase Pangkalan TNI AU Timika.

Dalam hal operasi non-militer, terkait dengan pengamanan wilayah yang berhubungan dengan perkembangan situasi sosial dan politik turut mewarnai peran Skuadron Udara 51 UAV. Pada pesta demokrasi/Pilkada Gubernur DKI Jakarta tahun 2017 silam, muncul warna baru pada perpolitikan Indonesia, dimana provinsi DKI Jakarta saat itu mengalami perkembangan penguatan politik identitas[21]. Skuadron Udara 51 UAV kemudian ditugaskan untuk membantu memantau situasi kondisi di lapangan melalui udara secara senyap. Skuadron Udara 51 UAV saat itu dinilai menjadi pilihan terbaik karena mampu melakukan pengawasan/pemantauan terhadap situasi politik yang berkembang di ibukota tanpa menimbulkan kegaduhan dan rasa ketidak nyaman. 
Pada perkembangan selanjutnya Skuadron Udara 51 UAV dilibatkan pada kegiatan pengamanan VVIP yang membutuhkan pengawasan dan pengamanan tingkat tinggi seperti pada pengamanan IMF (International Monetary Fund) and World Bank Annual Meeting 2018 serta pengamanan kegiatan Asian Games XVIII. Pelaksanaan IMF and World Bank Annual Meeting 2018 ini merupakan ajang pertemuan tahunan yang diselenggarakan oleh Dewan Gubernur IMF dan Gubernur Bank Dunia. Pertemuan ini dilaksanakan dari tanggal 9 Oktober sampai dengan 14 Oktober 2018, berlokasi di Nusa Dua, Benoa, Bali yang kemudian terselenggara secara lancar dan aman.

\section{Tantangan}

Berbagai keterlibatan Skuadron Udara 51 UAV telah menjadi bukti tersendiri, bahwa UAV mampu memberikan sokongan nyata pada operasi militer dan non-militer melalui penginderaan secara senyap dan akurat. Meski demikian muncul tantangan yang berkaitan dengan : Pertama, jangkauan dari UAV yang digunakan guna memberikan kemampuan surveillace yang lebih baik. Kedua, pemanfaatan data dan informasi yang dihasilkan, sehingga mampu memberikan manfaat tidak saja pada lingkup militer belaka akan tetapi juga pada lingkup non-militer sebagaimana telah dilakukan oleh Skuadron Udara 51 secara lebih nyata.

Koordinasi yang dilakukan oleh Skuadron Udara 51 UAV dengan institusi lain, baik militer maupun sipil menjadi kata kunci pemanfaatan yang lebih baik melalui kehadiran Skuadron Udara 51. Data dan informasi yang diberikan oleh Skuadron Udara 51 UAV dapat dijadikan bahan pertimbangan bagi para stake holders untuk strategi pengamanan wilayah, terutama untuk proses penanganan yang membutuhkan waktu segera. Kecepatan informasi dan data yang diberikan oleh teknologi UAV memberikan nilai lebih bagi proses pemantauan wilayah yang membutuhkan dukungan ketelitian yang tinggi. Serta Feed back atas hasil surveillance dari adanya potensi pelanggaran batas wilayah yang tidak terawasi oleh pasukan pengamanan perbatasan di darat belum berterima, padahal ini penting guna merumuskan pola pencegahan dari kasus-kasus serupa.

\section{KESIMPULAN}

Perkembangan teknologi terutama yang berkaitan dengan pemanfaatan UAV telah memberikan perubahan nyata pada model perang modern/keamanan wilayah. Efektivitas dan efisiensi yang diberikan melalui pemanfaatan UAV telah mampu menekan risiko seminimal mungkin jika dibandingkan dengan pola pengamanan wilayah yang dilakukan secara konvensional.

Skuadron Udara 51 UAV telah memberikan dan membuktikan andilnya dalam hal strategi pengamanan wilayah. Hal ini dibuktikan melalui berbagai keterlibatannya sesuai perintah tugas yang diberikan dalam berbagai operasi militer. Dengan mengacu pada keunggulan yang dimiliki oleh Skuadron Udara $51 \mathrm{UAV}$, maka dapat disimpulkan bahwa peran UAV dalam strategi pengamanan wilayah signifikan adanya. Kedepan, peningkatan keluasan jangkauan serta pemanfaatan hasil surveillance yang lebih luas dengan lintas institusi dapat terbangun lebih kuat dan lebih luas sehingga manfaat penggunaannya dapat lebih termaksimalkan. 


\section{DAFTAR PUSTAKA}

[1] https://www.worldometers.info/geography/largest-countries-in-the-world/ Accessed on 10th November 2021.

[2] Ralf Emmers and Sarah Teo, "Regional security strategies of middle powers in the Asia-Pacific", International Relations of the Asia-Pacific, 15(2), 185-216. 2015, DOI :10.1093/irap/lcu020

[3] Christine Aguis, "Ordering without bordering: drones, the unbordering of late modern warfare and ontological insecurity", Postcolonial Studies, 2017. DOI: 10.1080/13688790.2017.1378084

[4] Cory Welt and Andrew S. Bowen, "Azerbaijan and Armenia: The Nagorno-Karabakh Conflict", US Congresional Research Service, January 7, 2021

[5] Kementerian Pertahanan Indonesia, "Buku Putih Pertahanan Indonesia", 2015.

[6] E. Goh, "Meeting The China Challenge: The U.S. In Southeast Asian Regional Security Strategies", East-West Center, 2005.

[7] JA Russell, "Regional Threats and Security Strategy: The Troubling Case of Today's Middle East." Strategic Studies Institute, 2007.

[8] Katharine Hall Kindervater, "Drone strikes, ephemeral sovereignty, and changing conceptions of territory, Territory, Politics, Governance". http://dx.doi.org/10.1080/21622671.2016.1260493

[9] T. Larosa, "Redefining Indonesia's National Security in Ensuring the Survival of The Nation". Jurnal Pertahanan: Media Informasi Ttg Kajian \& Strategi Pertahanan Yang Mengedepankan Identity, Nasionalism \& Integrity, 5(1), 1-18. https://doi.org/10.33172/jp.v5i1.495, T. 2019.

[10] Alcides Eduardo dos Reis Peron, "The "Surgical" Legitimacy of Drone Strikes? Issues of Sovereignty and Human Rights in the Use of Unmanned Aerial Systems in Pakistan". Journal of Strategic Security, Vol. 7, No. 4, Special Issue: Future Challenges in Drone Geopolitics (Winter 2014), pp. 81-93

[11] A. Ahmad, Maynard, S. B., \& Park, S, "Information security strategies: Towards an organizational multistrategy perspective". Journal of Intelligent Manufacturing, 15(1), 1-20.T. 2019.

[12] Derek Gregory, "From a View to a Kill: Drones and Late Modern War", Theory, Culture \& Society 2011 (SAGE) Vol. 28(7- 8): 188^215 . 2011. DOI: 10.1177/0263276411423027

[13] Arif Mustofa, Lilly S. Wasitova, Lidia Rina Dyahtaryani, Resmanto Widodo. "The Use of Drones: From the Perspective of Regulation and National Defense and Security".Turkish Journal of Computer and Mathematics Education Vol.12 No.10, p. 670-677. 2021

[14] A. Infantono and A. Dhaneswara, "Model Conceptual Design Pada Hull Main Body UAV Combat Drone Quadrotor Sebagai Surveillance dan Repeater Radio VHF/UHF”, AAU-JDST, vol. 6, no. 1, pp. 25-40, Feb. 2021.

[15] Alan W. Dowd, "Drone Wars: Risks and Warnings", The US Army War College Quarterly, Number 1 Volume 43, Article 32013.

[16] Edward Fairhead, "Supplanting the spectacle of sacrifice: Drone warfare and the anti-spectacle of the safe military body". Journal Media, War \& Conflict 1-18. 2019. DOI: 10.1177/1750635219889081

[17] Bianca Baggiarini, "Drone warfare and the limits of sacrifice" , Journal of International Political Theory, Vol. 11(1) 128-144, 2015. DOI: $10.1177 / 1755088214555597$

[18] Francisco Klauser and Silvana Pedrozo, "Introduction: Power and space in the drone age", GeographischEthnographische Gesellschaft Zürich \& Association Suisse de Géographie. 2017.

[19] https://docplayer.info/54695625-Alur-laut-kepulauan-indonesia-alki-i-ii-iii.htm

[20] Ioannis Kalpouzos. 2018. Published 2018 by Oxford University Press.

[21] Dina Lestari, "Pilkada DKI Jakarta 2017: Dinamika Politik Identitas Di Indonesia", SIMULACRA, Volume 2, Nomor 1, Juni 2019. 